\title{
Physicochemical and Stability of Goat Cheese with Mono and Mixed Culture of Lactobacillus plantarum and Lactobacillus rhamnosus
}

\author{
Triana Setyawardani ${ }^{1}$, Winiati Pudji Rahayu ${ }^{2}$, Nurheni Sri Palupi ${ }^{2}$ \\ ${ }^{1}$ Department of Animal Production, Faculty of Animal Science, University of Jenderal Soedirman \\ Purwokerto 53123, Indonesia \\ 2Department of Food Science and Technology, Faculty of Agricultural Engineering and Technology, Bogor Agricultural \\ University, Bogor 16002, Indonesia \\ Corresponding author email: trianaunsoed@gmail.com.
}

\begin{abstract}
The purpose of the study is to asses the effect of the use of mono probiotic culture and mixed cultures of Lactobacillus plantarum and Lactobacillus rhamnosus on the physicochemical properties and its viability during storage. The soft cheeses were made through three treatments: (1) the use of Lactobacilllus rhamnosus culture, (2) the use of Lactobacillus plantarum culture and (3) the use of mixed cultures (Lactobacillus rhamnosus and Lactobacillus plantarum). The variables measured were the cheese texture (firmness and stickiness), proximate, $\mathrm{pH}$ of the product, and the number of $\mathrm{LAB}$. The results showed that cheese firmness ranged from 10.78 to $47.75 \mathrm{gf}$, cheeses stickiness was -8.23 to $-11.53 \mathrm{gs}$, cheese $\mathrm{pH}$ was $4.70-5.60$; number of cheese LAB was 8.59-9.69 log cfu/g. The content of protein, fat, and ash were $13.65-16.54 \%, 15.28-20.03 \%$, and $2.7-3.39 \%$, respectively. The conclusion of this study was that the soft cheeses with mixed cultures of L.rhamnosus and L.plantarum are potentially good to be developed as a probiotic food.
\end{abstract}

Key words: Soft Cheese, Lactobacillus rhamnosus, Lactobacillus plantarum, Culture

Abstrak. Penelitian bertujuan untuk mempelajari pengaruh penggunaan probiotik secara tunggal dan campuran dari Lactobacillus plantarum dan Lactobacillus rhamnosus terhadap sifat fisikokimia dan viabilitas BAL selama penyimpanan. Keju lunak susu kambing terdiri dari tiga perlakuan yaitu (1) menggunakan kultur Lactobacillus rhamnosus, (2) menggunakan kultur Lactobacillus plantarum dan (3) campuran kultur (Lactobacillus rhamnosus and Lactobacillus plantarum). Variabel yang diamati adalah tekstur keju, proksimat, pH produk dan jumlah BAL. Hasil menunjukkan bahwa ketegasan/keutuhan keju mempunyai kisaran 10,78-47,75 gf, kelengketan keju adalah -8,23 sampai - $11,53 \mathrm{gs}$, pH keju adalah 4,70-5,60; jumlah BAL keju adalah 8,59-9,69 log cfu/g. Kadar protein, lemak dan abu keju berturut-turut adalah 13,56-16,54\%; 15,28-20,03\% dan 2,7-3,39\%. Kesimpulan dari penelitian ini adalah bahwa keju lunak dengan kultur campuran dari L.rhamnosus dan L.plantarum berpotensi baik untuk dikembangkan sebagai makanan probiotik.

Kata kunci : Keju lunak, Lactobacillus rhamnosus, Lactobacillus plantarum, kultur

\section{Introduction}

Cheese as food is believed to have health benefit (Choi et al., 2012) due to bioactive peptide released during protein hydrolysis process and temperature treatment or microbial enzyme (Hafeez et al., 2014), the peptide has many benefits for health including antioxidant, antimicrobial, anti-hypertension and so on (Nagpal et al., 2011). Probiotics Lactic Acid Bacteria (LAB) in cheese will add functional properties of cheese because bacteria are beneficial to health through its role in improving the health of the digestive tract when consumed regularly and fairly. Probiotic bacteria in cheese must stay alive and survive during processing and storage of the product.
Cheese is milk curd coagulated with rennet, separated from the whey and pressed into a solid. Several types of soft cheese produced traditionally made from goat's milk, among other is Batzos produced as the utilization of whey from cheese making originated from Macedonia (Psoni et al., 2003), Camero fresh cheese produced in Spain (Olarte et al., 2001) and Galotry cheese of Greece (Kondyli et al., 2008); Himalayan cheese (Mushtaq et al., 2015).

During processing and storage of cheese, the number of LAB may experience a decrease in the number of the initial culture, but this decrease inthe number of $L A B$ is not as fast as other fermentation 
products, because the cheese has higher $\mathrm{pH}$, more solid of its consistency and a higher fat content and these condition safe favorable for microbial probiotic (Stanton et al., 1998a). The use of two bacterial cultures in the fermentation process is capable of converting lactose to lactic acid within 3-4 hours, but the single culture takes 12-16 hours (Gurakan et al., 2010). Probiotic cultures such as Lactobacillus casei, Lactobacillus plantarum and Lactobacillus rhamnosusin cheese making has the goal of improving the quality of products and the development of new functional food products.

The purpose of the study was to assess the effect of using single probiotic culture and a mixture of Lactobacillus plantarum and Lactobacillus rhamnosuson the physicochemical properties of soft goat cheese, and viability of LAB during storage.

\section{Materials and Method}

\section{Materials and starter culture preparation}

Raw milk to manufacture soft goat cheese was purchased from Pegumas Farm (Gumelar, Indonesia), Lactobacillus rhamnosus and lactobacillus plantarum isolated from goat milk Ettawa crossbreed (Setyawardani et al., 2011). Lactobacillus rhamnosus, and Lactobacillus cultures were refreshed in De Man, Rogosa and Sharpe Broth (MRS, Oxoid, UK) media at $37^{\circ} \mathrm{C}$ for 24 hours before inoculated. A total of $5 \%(\mathrm{v} / \mathrm{v})$ of pure culturein MRSB, was added to the goat milk to make starter culture. Milk containing the LAB cultures was incubated at $37^{\circ} \mathrm{C}$ for 6 hours.

\section{Manufacture of goat milk cheese}

Goat milk was provided from local goat farm ettawa cross breed as much as soft cheese with probiotic bacteria are selected in vitro and in vivo, namely $L$. rhamnosus and $L$. plantarum. The process of cheese was, according to (Walstra et al., 1999) and (Gardiner et al., 1998) which refers to the manufacturing of cheddar cheese with a few modifications. Modifications made were the filtering process which was immediately after the gel sheating, no cheddaring process, and no pressing process.

Cheese making was started by pasteurizing milk at a temperature of $65^{\circ} \mathrm{C}$ for 30 minutes, then lowering the temperature to $37^{\circ} \mathrm{C}$. The pasteurized milk was then added by starter culture as much as $5 \%(\mathrm{v} / \mathrm{v})$ and incubated again at $37^{\circ} \mathrm{C}$ for 6 hours. The milk was then added by animal rennet as much as $0.06 \mathrm{mlL}^{-1}$ and incubated at $37^{\circ} \mathrm{C}$ for two hours to form a gel. Gel was then cut into pieces and allowed to stand for 10-15 minutes. The heating was done at $40^{\circ} \mathrm{C}$ for 30 minutes. Filtering was applied to separate the whey, leaving a matrix called curd. The separated solids from the whey was added by salt as much as $2 \%(b / b)$, then stirred until evenly distributed. The cheese was packedin a container and stored at refrigerator temperature $\left(5^{\circ} \mathrm{C}\right)$.

\section{Cheese texture and chemistry test}

Testing texture according to (Buriti et al., 2007) was performed with Universal Testing Machine TA-XT2i type Stable Micro Systems (England). Cheese samples were shaped cylindrically shaped in a diameter of $2.4 \mathrm{~cm}$ and height $3.0 \mathrm{~cm}$. The cheese was cut and then placed at room temperature $\left(25^{\circ} \mathrm{C}\right)$ for 20 minutes prior to measurement. The variables measured were firmness and cheeses stickiness done using theTexture Expert of Windows 1.20 computer programs. Total protein content was analyzed by micro Kjeldhal method (AOAC, 2006) fat content with soxlet extraction method (AOAC, 2006), and ash content was analyzed with furnace method (AOAC, 2006). The $\mathrm{pH}$ value of the sample was analyzed by method (AOAC, 2006) Semisolid or solid samples were taken as much as 10 grams and $10 \mathrm{ml}$ of distilled water was added, homogenized, and thenthe $\mathrm{pH}$ was measured using a pHmeter.

\section{Lactic acid bacteria count}

Count of lactic acid bacteria in cheese sample was measured according to (Burns et al., 2008). As much as 20 gsample wasput into $180 \mathrm{ml}$ of $2 \%$ sterile sodium citrate $(b / v)$, then the sample was homogenized in a stomacher (Seward stomacher 80 Lab blender, UK) for three minutes. Homogen a test was taken as much as $1 \mathrm{ml}$ and diluted up to $10^{8}$. Samples from the three highest dilutions 
were taken as much as $1 \mathrm{ml}$ aseptically and put into a sterile petri dish. The sample was poured with MRSA medium and incubateat $37^{\circ}$ for 4 hours and each sample was done triplicate.

\section{Statistical analysis}

Data were analyzed by analysis of variance (ANOVA) and a post hoc test of Duncan was performed with SPSS ${ }^{\circledR} 17.0$ software.

\section{Results and Discussion}

\section{Cheese texture}

The average value of cheese texture (firmness and stickiness) made by the culture of different probiotic LAB are presented in Table1. The texture of probiotic soft cheese of this research has mean of firmness ranging 10.78$47.75 \mathrm{gf}$. The firmness of cheese texture varies with the use of different probiotic LAB. The highest mean was the samples of soft cheese with L.plantarum probiotic cultures, followed by amixed cultures (L. plantarum and L.rhamnossus), and the lowest mean was the soft cheese with probiotic L.rhamnossus.

Soft texture of the probiotic cheese L.rhamnossus was due to the higher water content than other treatments. The water content which is too high in protein matrix results in product which is less elastic and easily broken during the pressing process of cheese. This is because water plays role asplastiser. Water acts indirectly to lower the concentration of casein in the cheese matrix, so that the elasticity is reduced and the product is more easily broken (Fox et al., 2000; Delgado et al., 2011; Magenis et al., 2014). The average water content of soft cheese LAB probiotic $L$. rhamnossus was $60.07 \%$, where as for probiotics of cheese sample soft L.plantarum was $56.42 \%$ then followed by LAB mixture (L. rhamnossus and $L$. plantarum) of $58.20 \%$ (unpublished data). The results showed that the addition of single or mixed cultures resulted in differences in the level of soft cheese stickiness with a range of -
8.23 to-11.53 gs. Cheese obtained with L. plantarum treatment was the stickiest among those of the other treatments. Factors affecting the stickiness cheese are fat and casein which affect the cheese matrix formation (Bryant et al., 1995) argued that the the level of cheese stickiness is influenced by fat content which is the higher the fat content, the stickier will the cheese be. Cheeses stickiness is one of the characteristics of the texture profiles of cheese which is produced by casein matrix by means of trapping the fat globules. According to (Banks, 1998), the structure of cheese is influenced by the levels of protein, fat and water and biochemical activities during storage.

\section{Chemical characteristics of goat cheese}

Chemical characteristics of goat's milk soft cheese with the addition of different cultures of probiotic $L A B$ are presented in (Table 2). The average of protein content of soft cheese of this research ranged $13.65-16.54 \%$. The use of $L$. rhamnosus culture produced soft cheese with significantly lower protein levels than other treatments. On the other hand, the L. plantarum anda mixture culture (L. rhamnosus $+L$. plantarum) produced the same protein level.

Table 2 shows that the addition of probiotic cultures treatments affects the fat content of goat milk oft cheeses. The cheese has a fat content of $15.67-20.03 \%$. Addition of $L$. plantarum culture produced the lowest fat content i.e. 15.67 compared to the other treatments. The fat content of this study was higher than the results of (Buriti et al., 2007; Silveira et al., 2015) which is a $15.37 \%$. The ash content in soft cheese with the use of different cultures was significantly different in the treatment of mixed cultures (L. rhamnosus and L. plantarum) with other treatments and the average ash content was $2.58-3.59 \%$. The highest average of ash content of cheese samples of $L$. plantarum probiotic LAB (3.52\%), followed by soft cheeses of $L$. rhamnossus probiotic LAB (3.39\%) and the smallest was the 
mixture LAB probiotic soft cheese (2.58\%). The low levels of ash in the treatment of mixed

Table1. Average value of soft cheese texture using single and mixed cultures

\begin{tabular}{lll}
\hline Culture types & Firmness (gf) & Stickiness (gs) \\
\hline L. rhamnossus & $10.78 \pm 0.96^{\mathrm{a}}$ & $-8.23 \pm 0.67^{\mathrm{a}}$ \\
L.plantarum & $47.75 \pm 0.79^{\mathrm{c}}$ & $-11.53 \pm 0.76^{\mathrm{b}}$ \\
L.rhamnossus+L.plantarum & $34.73 \pm 1.30^{\mathrm{b}}$ & $-10.18 \pm 0.73^{\mathrm{ab}}$ \\
\hline
\end{tabular}

Data values were expressed as means $\pm S D(n=6)$ Means within the same column with different superscripts are significantly different at $p<0.05$ by Duncan's multiple range test.

Tabel 2. Chemicals composition of soft cheese with single and mixed cultures (\%)

\begin{tabular}{lccc}
\hline Culture types & Protein & Fat & Ash \\
\hline L. rhamnossus & $13.65 \pm 0.31^{\mathrm{a}}$ & $17.02 \pm 1.54^{\mathrm{a}}$ & $3.39 \pm 0.36^{\mathrm{b}}$ \\
L.plantarum & $15.43 \pm 1.28^{\mathrm{b}}$ & $15.28 \pm 0.75^{\mathrm{a}}$ & $3.35 \pm 0.29^{\mathrm{b}}$ \\
L.rhamnossus+L.plantarum & $16.54 \pm 0.67^{\mathrm{b}}$ & $20.03 \pm 1.28^{\mathrm{b}}$ & $2.58 \pm 0.20^{\mathrm{a}}$ \\
\hline
\end{tabular}

Data values were expressed as means $\pm S D(n=6)$ Means within the same column with different superscripts are significantly different at $p<0.05$ by Duncan's multiple range test.

cultures (L. rhamnosus and L.plantarum) was suspected that the mixed cultures require more minerals during cheese making than single culture, consequently minerals remaining in the curd cheese decreased.

\section{The $\mathrm{pH}$ value of cheese}

The LAB probiotics activity during processing and storage of the products can be observed by looking atthe $\mathrm{pH}$ changes and the amount of $\mathrm{LAB}$. The $\mathrm{pH}$ data during storage is presented in Figure 1.

Soft cheese storage for four weeks lowered the $\mathrm{pH}$ of the product. The decrease in $\mathrm{pH}$ begins in the second week to the third week of storage. The average $\mathrm{pH}$ during the four weeks of storage was at 4.7-5.6 with the lowest $\mathrm{pH}$ observed in the addition of culture L.plantarum treatmentand the highest was in the addition of probiotic L.rhamnosus and mixed cultures. Additionof L.plantarum resulted in the lowest $\mathrm{pH}$ (5.0) among all treatments $(\mathrm{pH} 5.7$ for L.rhamnosus and $\mathrm{pH} 5.2$ the for the treatment of mixtures).

The decrease in $\mathrm{pH}$ is due to the continuing lactic acid production process and the presence of other organic acids produced by the starter and probiotic cultures (Buriti et al., 2007). The added LAB cultures will lower the $\mathrm{pH}$ of milk by changing the milk lactose into lactic acid. Gel formation of cheese is also affected by $\mathrm{pH}$ and temperature. At pH of 5.25 gels formed is solittle because the binding between the micelles are very weak. At low temperatures, the binding between the gel particles is stronger (Walstra et al., 1999). At the end of products storage, the $\mathrm{pH}$ increased approaching the initial $\mathrm{pH}$. The increased $\mathrm{pH}$ was due to the increased metabolic activities of yeast and molds hat utilize lactic acidas the carbon source and or the process of proteolysis by releasing large amounts of alkaline components.

\section{Lactic acid bacteria count}

The highest $L A B$ culture in L.rhamnosus curds was $8.64 \log \mathrm{cfu} / \mathrm{g}$; $9.83 \mathrm{log} \mathrm{cfu} / \mathrm{g}$ for L.plantarum and $10.04 \log \mathrm{cfu} \mathrm{g}^{-1}$ for mixed cultures. The results of counting the number of $L A B$ during four weeks of storage are presented in (Table 3).

Cheese made with L.rhamnosus, L.plantarum and mix (L.rhamnosus and L.plantarum) cultures did not experience a decrease in the number of $L A B$ during four weeks of storage. This shows the well ability of $L A B$ to live on cheese products and the indication of well adaptability of $L A B$ ncheese matrix environment, during the four 
weeks. This was caused by the removal of most lactose during whey separation and only little amount of lactose remained. The increase in lactic acid content during the first few weeks of

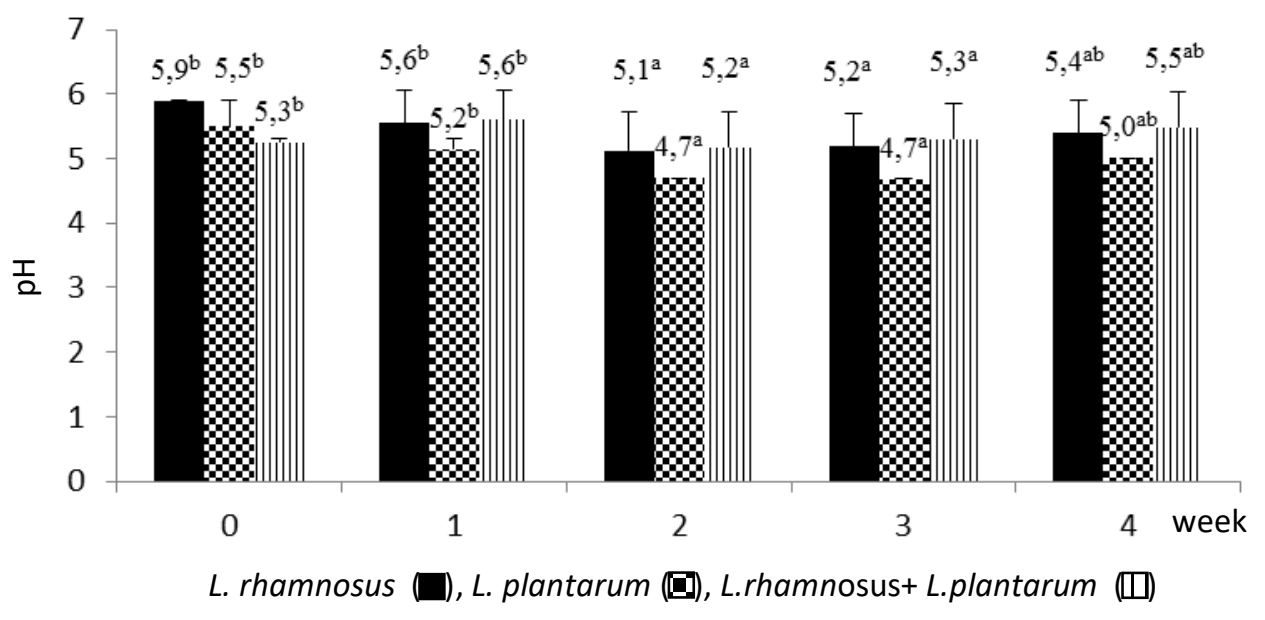

Figure 1 . The changes of soft cheese $\mathrm{pH}$ store for four weeks

Tabel 3. Change of lactic acid bacteria count in soft cheese stored for four weeks (log cfug ${ }^{-1}$ )

\begin{tabular}{lccccc}
\hline \multirow{2}{*}{ Cultural types } & \multicolumn{5}{c}{ Ripening period (week) } \\
\cline { 2 - 6 } & $0^{1}$ & 1 & 2 & 3 & 4 \\
\hline L.rhamnosus & $8.58 \pm 0.13^{\mathrm{a}}$ & $8.76 \pm 0.07^{\mathrm{a}}$ & $8.68 \pm 0.18^{\mathrm{a}}$ & $8.49 \pm 0.09^{\mathrm{a}}$ & $8.59 \pm 0.14^{\mathrm{a}}$ \\
L.plantarum & $10.04 \pm 0.21^{\mathrm{a}}$ & $9.88 \pm 0.13^{\mathrm{a}}$ & $9.93 \pm 0.44^{\mathrm{a}}$ & $9.89 \pm 0.27^{\mathrm{a}}$ & $9.87 \pm 0.24^{\mathrm{a}}$ \\
L.rhamnosus+ L.plantarum & $9.83 \pm 0.21^{\mathrm{a}}$ & $9.56 \pm 0.05^{\mathrm{a}}$ & $9.67 \pm 0.17^{\mathrm{a}}$ & $9.58 \pm 0.15^{\mathrm{a}}$ & $9.69 \pm 0.12^{\mathrm{a}}$ \\
\hline
\end{tabular}

cfu : colony forming unit, Values are mean \pm SD $(n=6)$.

${ }^{1} 0$ month means the sample obtained after 48 hours from cheese making. Values within the same column with different superscripts are significantly different at $p<0.05$ by Duncan's multiple range test.

storage is caused by fermentation of lactose remained in the cheese (Ong et al., 2007). The population of $L A B$ in the cheese reduce during processing and storage, although the rate of decrease is lower when compared to other fermented milk. This is due to the high $\mathrm{pH}$ of cheese with denser consistency and higher fat content, that provide protection to the $L A B$ during storage and digestion by the gastrointestinal tracts. The population of $L A B$ in the cheese reduce during processing and storage, although the rate of decrease is lower when compared to other fermented milk. This is due to the high $\mathrm{pH}$ of cheese with denser consistency and higher fat content, that provide protection to the LAB during storage and digestion by the gastrointestinal tracts (Stanton et al., 1998b)
These microbes should be able to survive the conditions of the stomach and digestive tract so it is useful to maintain the balance of intestinal microbial populations. In cheese making, the number of LAB probiotic cheese is one of the requirements that must be met to obtain functional benefits. It is recommended to consume $10^{8}-10^{9} \mathrm{cfu}$ in each serving to obtain health benefits (Araújo et al., 2010). The number of LAB trapped in the gel matrix formed after the addition of rennet also reached $10^{8} \mathrm{cfu} / \mathrm{g}$ so that it has the potential tobe developed into probiotic food product.

The study was designed to assessand to evaluated the effect of using single probiotic culture and a mixture of L.plantarum and L.rhamnosus on the physicochemical properties of goat cheese, and count of LAB during storage. The data from current study indicated that 
mixed cultures (L. rhamnosus and L.plantarum) in soft goats milk cheese has better texture, higher number of LAB, higher protein content, than the culture of L. rhamnosus. Soft cheeses made with mixed cultures (L. rhamnosus and $L$. plantarum) were potential to be developed as functional cheese.

\section{Conclusion}

Mixed cultures (L.rhamnosus and L.plantarum) in soft goats milk cheese has better texture, higher number of $L A B$, higher protein content, than the culture of $L$. rhamnosus. Soft cheeses made with mixed cultures (L. rhamnosus and $L$. plantarum) were potential to be developed as functional cheese.

\section{Acknowledgement}

We would like to thank to Dr. RRA Maheswari and Juni Sumarmono PhD for their contribution in the paper corection and preparation.

\section{References}

AOAC [Association of Official Analytical Chemists]. 2006. Official Method of Analysis. $15^{\text {th }}$ Ed. Association of Official Analytical Chemists Inc., Virginia USA.

Araújo EA, AF de Carvalho, ES Leandro, MM Furtado and CA de Moraes. 2010. Development of a symbiotic cottage cheese added with Lactobacillus delbrueckii UFV $\mathrm{H} 2 \mathrm{~b} 20$ and inulin. Journal of Functional Foods 2:85-89.

Banks JM. 1998. Cheese. In: R. Early (ed.) The Technology of Dairy Products. p 81-122. Blackie Academic and Professional, London, UK.

Bryant A, Z Ustunol and J Steffe. 1995. Texture of Cheddar cheese as influenced by fat reduction. J. Food Sci. 60:1216-1219.

Buriti FC, HR. Cardarelli, TM Filisetti and SM Saad. 2007. Synbiotic potential of fresh cream cheese supplemented with inulin and Lactobacillus paracasei in co-culture with Streptococcus thermophilus. Food Chem. 104:1605-1610.

Burns P, F Patrignani, D Serrazanetti, G Vinderola, J Reinheimer, R Lanciotti and M Guerzoni. 2008. Probiotic Crescenza Cheese Containing Lactobacillus casei and Lactobacillus acidophilus Manufactured with High-Pressure Homogenized Milk. J. Dairy Sci. 91:500-512.
Choi J, L Sabikhi, A Hassan and S Anand. 2012. Bioactive peptides in dairy products. Int J Dairy 65:1-12.

Delgado FJ, J González-Crespo, R Cava and R Ramírez. 2011. Proteolysis, texture and colour of a raw goat milk cheese throughout the maturation. European Food Research and Technology 233: 483-488.

Fox T, M Cogan, TP Guinee and PLH McSweeney. 2000. Fundamental of Cheese Science. Aspen Publishers. Maryland. USA.

Gardiner G, R Ross, J Collins, G Fitzgerald and C Stanton. 1998. Development of a Probiotic Cheddar Cheese Containing Human-Derived Lactobacillus paracaseiStrains. Applied and environmental microbiology 64:2192-2199.

Gurakan G, Candan, Altay and Neslihan. 2010. Yogurt Microbiology and Biochemistry. In: F. Yildiz (ed.) Development and Manufacture of Yogurt and Other Functional Dairy Products. p 97-122. CRC Press. Boca Raton. USA.

Hafeez Z, C Cakir-Kiefer, E Roux, C Perrin, L Miclo and A. Dary-Mourot. 2014. Strategies of producing bioactive peptides from milk proteins to functionalize fermented milk products. Food Res Int 63, Part A:71-80.

Kondyli E, M Katsiari and L Voutsinas. 2008. Chemical and sensory characteristics of Galotyri-type cheese made using different procedures. Food Control 19:301-307.

Magenis RB, ES Prudêncio, CB Fritzen-Freire, MP Stephan, A Silvio do Egito and H Daguer. 2014. Rheological, physicochemical and authenticity assessment of Minas Frescal cheese. Food Control 45:22-28.

Mushtaq M, A Gani, PH Shetty, FA Masoodi and M Ahmad. 2015. Himalayan cheese (Kalari/kradi): Effect of different storage temperatures on its physicochemical, microbiological and antioxidant properties. LWT - Food Science and Technology 63:837-845.

Nagpal R, P Behare, R Rana, A Kumar, M Kumar, S Arora, F Morotta, S Jain and H Yadav. 2011. Bioactive peptides derived from milk proteins and their health beneficial potentials: an update. Food \& function 2:18-27.

Olarte C, E Gonzalez-Fandos and S Sanz. 2001. A proposed methodology to determine the sensory quality of a fresh goat's cheese (Cameros cheese): application to cheeses packaged under modified atmospheres. Food Qual Prefer 12:163-170.

Ong L, A Henriksson and NP Shah. 2007. Proteolytic pattern and organic acid profiles of probiotic Cheddar cheese as influenced by probiotic strains of Lactobacillus acidophilus,Lb. paracasei, Lb. casei or Bifidobacterium sp. Int Dairy J. 17:67-78. 
Psoni L, N Tzanetakis and E Litopoulou-Tzanetaki. 2003. Microbiological characteristics of Batzos, a traditional Greek cheese from raw goat's milk. Food. microbiology 20:575-582.

Setyawardani T, W Rahayu, R Maheswari and N. Palupi. 2011. Identification and characterization of probiotic lactic acid bacteria isolated from indigenous goat milk. Animal Production 13.

Silveira EO, JH Lopes Neto, LAd Silva, AES Raposo, M Magnani and HR Cardarelli. 2015. The effects of inulin combined with oligofructose and goat cheese whey on the physicochemical properties and sensory acceptance of a probiotic chocolate goat dairy beverage. LWT - Food Science and Technology 62:445-451.

Stanton C, G Gardiner, P Lynch, J Collins, G Fitzgerald, and R. Ross. 1998a. Probiotic cheese. International Dairy Journal 8:491-496.

Stanton C, G Gardiner, P Lynch, J Collins, G Fitzgerald and R Ross. 1998b. Probiotic cheese. Int Dairy J. 8:491-496.

Walstra P, TJ Geurtz, A Noomen, A Jellema and MAJS van Boekel. 1999. Dairy technology: principles of milk properties and processes. Marcel Dekker Inc. New York. USA. 